\title{
Individual Performance, Leadership Succession, Organizational Climate and Moderating Effect of Trust: Data Screening and Preliminary Analysis
}

\author{
Abdulkadir Musa Badara \\ Ph.D. Student in Management, \\ Email: abdulkadir_musa@yahoo.co.uk \\ Husna Bt Johari
}

School of Business Management, College of Business, University Utara Malaysia

Tan Fee Yean

School of Business Management, College of Business, University Utara Malaysia

\section{Doi:10.5901/mjss.2015.v6n2p13}

\begin{abstract}
The main objective of this paper is to present individual performance, leadership succession, organizational climate and moderating effect of trust, data screening processes in the Nigerian commercial banks. Data of the study were collected through research assistant employed, in which 600 questionnaire were sent to employees of the commercial banks. Data were analyzed using Statistical Package for Social Science (SPSS) version 20. Thus, response rate and non-respond biased were ascertained, data cleaning, detection of missing data, treatment of univariate and multivariate outliers and descriptive statistics and correlation. The result revealed that the data is suitable for further analysis.
\end{abstract}

Keywords: individual performance, leadership succession, organizational climate, trust, data screening, commercial banks, Nigeria

\section{Introduction}

Individual performance has long been considered as one of the key factors that can lead to the growth and development of any organization (Judge \& Ferris, 1993). Individual performance is very important to encourage individuals, and discourage laziness that can impede group morale in an organization (Murphy \& Cleveland, 1995; Scott \& Einstein, 2001). This is because an individual who performs better will be rewarded while those who perform poorly will be sacked or penalized. Nevertheless, individual employees contribute to the growth and development of an organization, most especially individuals who are highly resourceful (Mollick, 2012).

Organizations usually take more effort to recruit the highest performing individuals, because an employee who performs excellently is an asset to the organization (Drucker, 1998). Burkus (2012) stated that organizations need to deliberate which company resources improve employees' performance such as computer systems or knowledge resources, and look out for ways to increase their use. According to Drucker (1998), individual performance is reliant on more than just the knowledge he or she has. Performance depends on the ability of the individual to work hard in order to achieve the organization's goals.

Performance of individual employees in the Nigerian commercial banking sector is one of the key factors that may lead to the growth and development of most economies, because good performance of individual employees determines the growth of the banking sector specifically and the Nigerian economy as a whole. Additionally, performance of individuals in the banking sector over along period of time is a sign of business strength in any country (Kolapo, Ayeni, \& Oke, 2012). Randle (1995) suggested that it is very important for banks to make some changes in their day -to-day operational activities above local to global competitiveness, because of the advancement in globalization of financial markets.

The main objective of the study is to ascertained data screening processes and preliminary analysis with regards to individual performance, leadership succession, organizational climate and moderating effect of trust in the Nigerian commercial banks. The study is expected to make contributions to the general body of knowledge significantly by integrating individual performance, leadership succession, organizational climate and moderating effect of trust in one 
study in order to see their relationship and how they contribute to growth and development of not only the Nigerian banking industry but the economy as a whole. The study is also expected to benefit the commercial banks, managers, business practitioners, the Nigerian government, academics and other students towards enhancing their knowledge and understanding concerning the influence of individual performance, leadership succession, organizational climate and moderating effect of trust in Nigeria.

\section{Literature Review}

\subsection{Individual Performance}

Numerous scholars have defined individual performance in so many ways. For example, Pugh, (1991) defined individual performance as the degree to which individual's achieve their goals in an organizations through hard work. It is also the level of individuals' output as a result of an activity (Erat et al., 2012). Individual performance is also defined as the amount of individual contribution to the development effort as captured by the number of defects fixed by individuals in an organization (Ehrlich \& Cataldo, 2012). Campbell (1990) defined individual performance as "behaviors or activities that are related to the objectives of the organization". For the purpose of this study, individual performance refers to the process where by individual employees achieve better performance in an organization through hard work.

Individual performance is the creation of the entire performance of any business, because it is the performance of individual employees that determines the prospects of the organization. Additionally, the main objective of individual performance is to support the projected ways of employees' activities in order to elevate the performance of the organization as a whole to achieve the desired goals (Adiguzel, Yuksel \&Tekin, 2010). Employee performance is important for the effectiveness, achievement and performance of an organization because effective performance of the individual employees determines the progress and survival of the organization. Additionally, employees are also the main resources of every business entity, because when employees are inspired and satisfied, they will always execute their responsibilities diligently and vigorously (Akram, 2012).

\subsection{Leadership succession}

Leadership successions are warning sign events in organizations' which are always influenced by the business drive as predecessors to strategic reorientations in order to achieve good individual performance (Ndofor, Priem, Rathburn, \& Dhir, 2009). Leadership succession is a procedure which offers an opportunity or chance for the alteration of the existing power contact, for the introduction of better strategic system and for change to occur (Boeker, 1997). Leadership succession can also be seen as a situation where a new leader takes the place of a departing leader and takes over all the rights and responsibilities of that position (Hutzschenreuter, Kleindienst \& Greger, 2012). Succession is a proactive procedure in order to ensure that there is continuing leadership loyalty to the organization's values, mission and strategic plan by deliberately developing employees within the organization (Jamye, Johnson, Faught, \& Street 2013).

Succession comes about when a firm or organization announces the nomination of a new Chief Executive Officer (CEO) (Graffin, Carpenter \& Boivie, 2011). The announcement of CEO change sends a very strong indication that the person accountable for the weak performance is about to be replaced and that his successor can move the organization to greater success (Liu, Valenti \& Yu, 2011). CEO nominations are normally made behind closed doors, thus information on how board members choose a CEO is not shared (Shen \& Cannella, 2003). These permit the leadership of a firm to resolve how, what and when information is shared. Because this procedure takes place secretly, members of the financial press recording the event, as well as shareholders, do not have access to information until when the leaders in the organization agree to release the result (Graffin et al., 2011).

Helfat and Bailey (2005) suggested that board members expect that the newly appointed leader will make changes and will impose a mandate for improving the organization's strategies, vision, mission, and goals for better performance. When leadership succession take place, a new person, with new perceptions, new point of view and skills, including new ideas on the kind of markets in which a firm should strive and takes over the organization. Thus, succession often means change in the process or approach in which a firm operates; it also indicates that the existing norms and beliefs within the organization might be changed (Boeker, 1997).

\subsection{Organizational climate}

The study on organizational climate started in the 1960 s as a main concept in researching on individuals in an 
organization (Litwin \& Stringer, 1968; Friedlander \& Marguiles, 1969). It has also been emphasized as a major factor of employee performance, job behaviors and firm success (Abdel-Razek, 2011) it is therefore worthy of deeper concern in relation to specific national contexts. The concept of organizational climate was introduced to describe the environment and settings in which individuals are expected to operate, with regards to the emotional, organizational, situational and social influences employed (Argyris, 1958; Forehand \& von Gilmer, 1964; Guetzkow et al., 1962). Organizational climate encompasses organizational structure and process, interpersonal relationships, compensation administration, employee behavior, performance expectation and opportunities for growth (Bamel, Rangnekar, Stokes \&Rastogi, 2013).

In the view of Pareek (1989), organizational climate is an outcome of interaction among firm's components such as structure, systems, culture, leader's behavior and employees' psychological needs. Denison (1996) asserted that organizational climate is the way in which organizational members perceive and characterize their environment in an attitudinal and value-based manner. Organizational climate is a social structure that can either promote performance, and thus be considered a shield between individual skills and motivation; and various work outcomes (Schneider, 1975). Additionally, it has also been found to be one of the important elements associated with the organization. For the organizations to gain strength and success, it is important to build a climate that facilitates and supports creativity (Imran, Saeed, Anis-ul-haq \& Fatima, 2010).

Organizational climate also emulates shared beliefs of the members and psychological meanings they give to the environment in order to make sense out of it (Schneider and Reichers, 1983). It also interprets perception of the work situation, characteristics of the organization and the nature of employees' relationship with other people on the job (Churchill, Ford \& Walker, 1976).

\subsection{Trust}

Trust has gradually become essential to the study of organizations, because of the strong need to understand how to build effective co-operation within organizations (Tyler, 2003). Thus, trust is very important in an organization because it enables cooperation. Several scholars have defined trust in different ways; for example, according to Zand (1972), trust is an emotional state that makes an individual vulnerable to a third party. Mayer and Colleagues (1995) defined trust as the willingness of a party to be free to the actions of another party based on the anticipation that the other party will perform a certain action that is important to the trustee, irrespective of the ability to monitor or control the other party.

Trust leads to proper understanding and cordial relationships between top management and lower levels in an organization. Additionally, individuals who are perceived to be honest, have the abilities to receive accurate information and better performance -related resources from their co-workers or supervisors than individuals who are not trustworthy (Dirks \& Sharlicki, 2009). Similarly, individuals who trust each other are more willing to share important ideas and comprehensive information, clear up problems and share long-term goals (Revilla \& Knoppen, 2012).

Furthermore, trust serves as a moderating variable because a moderating variable is a variable that affects the connection between the independent and dependent variables (Bennett, 2000). Sekaran and Bougie (2010) also noted that a moderating variable is a variable that has strong contingent effect on the relationship between the independent and dependent variables. Previous studies (e.g., Frost \& Moussavi, 2011; Talmud \& Gadot, 2010; Farndale, Hailey \& Kelliher, 2010; Chang \&Wong, 2010; Mulder, Verboon\& Cremer, 2009; Liu, 2010) suggested that further studies need to be carried out on trust as a moderating variable because there are currently few studies on trust especially in the Nigerian banking industry.Therefore, in this study, trust is expected to enhance the relationship among leadership succession, organizational climate and indidivual performance in the Nigerian banking industry.

\section{Methodology}

Leedy and Ormrod (2005) stated that in order to answer questions related to relationships among measured variables, quantitative method is employed because it has the capability in explaining, predicting and controlling phenomena. Therefore, based on Leedy and Ormrod (2005) explanation, quantitative method is used in this study to answer the research questions. Creswell (2003) also stated that quantitative method is better and the most suitable method due to its fast turnaround in data collection. Data for this study were obtained through a survey questionnaires administered to the individual employees of the Nigerian commercial banks. The population of the study is the commercial banks from six states in the six regions of the country Nigeria. There are 1,645 commercial banks branches in six states of the region, based on this population, the sample size was drawn from Krejcie and Morgan's (1970) table for sample size determination, based on the selected 310 employees from the branches.

Therefore, in order to take care of none response rate and minimize it as suggested by Hair, Wolfinbarger and 
Ordinal (2008); and Hair, Black, Babin and Anderson (2010), the sample size was doubled and a total of 600 questionnaires. The sampling method was stratified random sampling, in which the populations were divided into stratum i.e., geo-political zones. However, this study used the stratified simple random sampling method because it is suitable for the study. This type of sampling technique provides equal chance to every respondent of being selected as a sample (Sekaran, 2003). According to Salkind (2003), this type of sampling technique has an advantage because it has no bias of the researcher against the choice of the sample. Thus, the questionnaires were administered and collected through the use of research assistants employed from each of the selected states of the geographical zones in order to assist quick responses and also to facilitate the realization of high response rate. The data were keyed in SPSS version 20 for further analysis.

\section{Results and Discussion}

A total of 471 questionnaires were duly completed and returned representing $78.5 \%$ response rate. Out of the 471 questionnaires collected from the respondents, 21 questionnaires were returned incompleted. Thus, only 450 questionnaires (75\%) were coded and used for further analysis as depicted in Table 1.

Table 1: Response rate for the questionnaire

\begin{tabular}{lcccccccc}
\hline Responses & \multicolumn{1}{c}{ Bauchi } & Kano Abuja & Lagos & Delta & Abia & Total/rate \\
\hline Distributed questionnaire & 150 & 200 & 100 & 80 & 50 & 20 & 600 \\
Retumed questionnaire & 150 & 175 & 65 & 34 & 27 & 20 & 471 \\
Retumed and usable questionnaire & 142 & 170 & 58 & 33 & 27 & 20 & 450 \\
Retumed and excluded questionnaire & 7 & 5 & 6 & 3 & 0 & 0 & 21 \\
Questionnaire not retumed & 0 & 25 & 35 & 46 & 23 & 0 & 129 \\
Response rate & $100 \%$ & $87.5 \%$ & $65 \%$ & $42.5 \%$ & $54 \%$ & $100 \%$ & $78.5 \%$ \\
Usable response rate & $94.6 \%$ & $85 \%$ & $58 \%$ & $41.3 \%$ & $54 \%$ & $100 \%$ & $75 \%$ \\
\hline
\end{tabular}

A total of 450 respondents constituted the sample size for this research which indicates a good response rate of $75 \%$ which covers all employees of commercial banks in the six states of the region. This rate is considered sufficient based on the argument of Sekaran (2003) that a response rate of $30 \%$ is suitable for survey. In addition, the present response rate is considered sufficient as it is suggested that a sample size should be between five and 10 times the number of study variables to carry out regression analysis (Hair et al., Barlet et al., Pallant, 2001). Since this study has four variables, a sample of 40 is considered adequate for data analysis. Thus, 450 responses (75\%) was used which satisfied the required sample size for multiple regression analysis. The data was keyed into SPSS version 20 for further analysis.

\subsection{Non Response Bias}

The issue of non- response bias refers to the common mistake a researcher makes in assessing the characteristics of the sample because some groups of respondents are understated due to non-response (Berg,2002). Singer (2006) stated that there is no minimum response rate below which a survey estimate is necessarily biased; there is also no response rate above which it is never biased. Nevertheless, there is need to investigate the possibility of bias no matter how small the non- response bias is (Pearl \& Fairly, 1985; Sheikh, 1981). The respondents were divided into two major independent samples based on their response to survey questionnaire with regards to four major study variables leadership succession, organizational climate, individual performance and trust.

Table 2: Descriptive statistics for early and late respondents

\begin{tabular}{clcccc}
\hline & Collection period & $\mathrm{N}$ & Mean & Std. Deviation & Std. Error Mean \\
\hline IP & Early response & 194 & 1.4646 & .26864 & .01929 \\
& Late response & 256 & 1.5044 & .33401 & .02088 \\
LS & Early response & 194 & 1.4779 & .33791 & .02426 \\
& Late response & 256 & 1.4810 & .30958 & .01935 \\
$\mathrm{O}$ OC & Early response & 194 & 1.2938 & .29266 & .02101 \\
& Late response & 256 & 1.4596 & .31536 & .01971 \\
TR & Early response & 194 & 1.3325 & .33030 & .02371 \\
& Late response & 256 & 1.3711 & .30835 & .01927 \\
\hline
\end{tabular}


One of the methods of testing non-response bias is by comparing the responses of the early respondents and the respondents who response lately. The responses of those respondents who respond late are in essence, a sample of non-respondents to the first questionnaire administered and that is presumed to be the representative of the non respondents' group (Miller \& Smith, 1983; Oppenheim, 1966).

Table 3: Independent Samples T- Test for Equality of Means

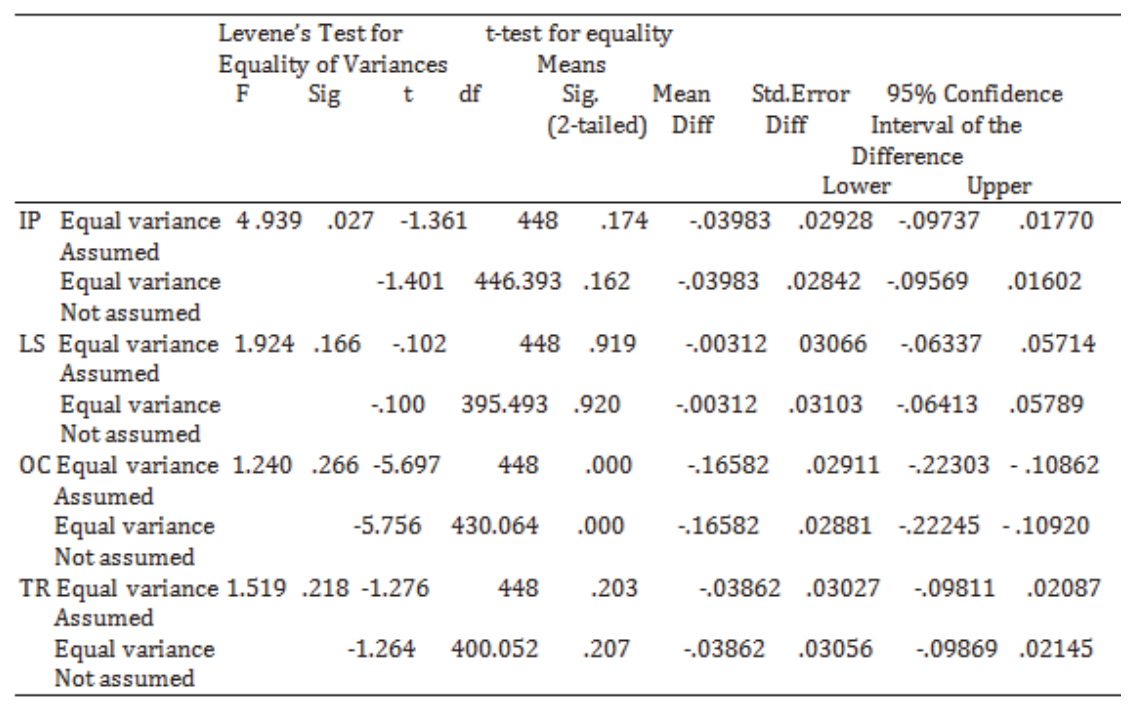

From the independent sample t-test for equality of means, the result above shows that the group mean and standard deviation for early respondents and late respondents are actually not different. As indicated in Table 3, the t-test shows that there is no significant difference between early responses and late responses based on the items in individual performance ( $t=-1.401, P>.162)$; leadership succession (-.102, $\mathrm{P}>.919)$; organizational climate $(\mathrm{t}=-5.697, \mathrm{P}<.000)$; and trust $(\mathrm{t}=-1.276, \mathrm{P}>\mathrm{.203})$ respectively. Thus, as the result indicates, though the items are statistically different, the differences are relatively small and not significant enough to have an effect on the entire results. However, the questioniares that were received in the first month of the data collection were marked as early responses while the remaining that came in the second month were marked as late responses.

\subsection{Data Cleaning}

Data cleaning is very important for conducting any multivariate analysis. This is because the quality and good result of the analysis depend on the data screening and editing (Pallant, 2011). But before the actual data cleaning, negetively coded questions were transformed e.g., 1 was tranformed to 5,5 to 1,2 to 4 , and 4 to 2 .

\subsection{Detection of Missing Data}

Missing data refers to absence of appropriate value on one or more variables for data analysis (Hair, Black, Babin \& Anderson, 2010). In understanding the negative effect of missing data, the researcher took a preventive action right from the field in an attempt to reduce and ensure that the data is free from any missing value. Therefore, upon receiving any completed questionnaire, the researcher and his research assistants quickly made sure that each and every question is properly answered. In some cases, if a questionnaire is not properly filled in, the attention of the respondent was quickly drawn to kindly complete appropriately. The researcher also followed the data entry step by step with caution and curiosity. After receiving the data, the researcher keyed in the data in SPSS version 20 software. Whenever a missing value is detected, the researcher has to refer to the questionnaire and trace it. Hence, this helps in certifying that no missing value is detected. A preliminary descriptive statistics was conducted to find out if there are missing values or not. The result of the descriptive statistics indicates that no missing value was recorded; thus, there is no need for deletion. According to Hair et al. (2010), any case with more than $50 \%$ missing value should be deleted as long as there is adequate sample. However, there was no missing value recorded in this study. 


\subsection{Outliers}

Outliers are those cases whose scores are significantly different from others in a given set of data (Byrne, 2010). Tabachnich and Fidel (2007) recommended the identification of univariate outliers through observation of the z score. The $z$ score of every item must be within the range of \pm 3.29 ( 0.05 sig. level) which is inline with (Tabachnich \& fidel, 2007). Based on this investigation, any values that exceed \pm 3.29 are due to the mistake made during data entry. A total of 53 cases of univariate outliers were recorded. In order to identify multivariate outliers, Mahalanobis distance was examined. All the cases with Mahalanobis distance exceeding 129.80 at degree of freedom 84 were deleted. Here 84 means the number of items used for the analysis. Therefore, 11 cases were deleted because they were above the critical value of 129.80. Mahalanobis distance was re-conducted and no more outliers in the data set were found. This meant that 386 cases were retained and used for subsequent analysis.

\subsection{Descriptive Statistics}

Prior to the descriptive analysis, e.g. mean and standard deviation were be carried out. Mean is usually used measure central of tendency. Mean refers to the average value of data set. It provides the whole picture of a data set without inundating one with each of the observations (Sekaran \& Bougie, 2010). Standard deviation is a technique of dispersion which offers an index of variability in the data and is the square root of variance. Both the mean and the standard deviation are common descriptive statistics for interval and ratio scale. The five point likert scale was used as the measurement scale of this study. To interpret the level of score, the researcher used the recommendation of Nik Muhammad, Jatan and Md Taib (2010) which stated that scores of less than $2.33(4 / 3+1$ (lowest value)) are low level; 2.33-3.66 are moderate level; and 3.67 (5 (highest value)- 4/3) and above are considered high level. Contextual performance has the highest mean recorded $(M=3.80, S D=.741)$; while wellbeing recorded the lowest mean $(M=3.60$, $S D=6.43$ ). All the variables' means are within the range of high level. The Table below presents the mean and the standard deviation of the variables in the study.

Table 4. Mean and Standard Deviation for study variables

\begin{tabular}{ccc}
\hline Study Variables & Mean & Standard Deviation \\
\hline IP & 3.61 & .656 \\
AP & 3.72 & .692 \\
TP & 3.63 & .612 \\
CP & 3.80 & .741 \\
OC & 3.79 & .731 \\
IG & 3.63 & .703 \\
QT & 3.73 & .715 \\
WB & 3.60 & .643 \\
LS & 3.70 & .608 \\
TR & 3.64 & .656 \\
\hline
\end{tabular}

Note: $\mathrm{IP}=$ Individual performance, $\mathrm{AP}=$ Adaptive performance, $\mathrm{TP}=$ Task performance, $\mathrm{CP}=$ Contextual performance, $\mathrm{OC}=$ Organizational climate, IG = Integration, QT = Quality, WB = Wellbeing, LS = Leadership succession and TR= Trust.

\subsection{Correlation}

Pallant (2011) asserted that correlation analysis is used to explain the strength and direction of linear relationship between two variables. In determining the strength to the relationship, Pallant (2001) stated that a correlation of 0 indicates no relationship at all, a correlation of 1.0 is an indication of positive correlation and a value of -1.0 is a pointer of a perfect negative correlation. Cohen (1988) suggested the following guidelines: $r=0.10$ to 0.29 small; $r=0.30$ to 0.49 medium; $r=0.5$ to 1.0 large. Correlation is significant at 0.01 level (2-tailed). The result of pearson correlation is presented in Table 5.

Additionally, the correlation analysis of the variables under study was subjected to a two tailed test of statistical significance at two different levels; significant $(p<0.01)$ and significant $(p<0.05)$. Table 4.14 shows that correlation between all the variables under study are statistically significant at $(p<0.01)$ and $(p<0.05)$. It can also be seen from the same table that the correlation of the variables ranges from -.004 to .786. The table below indicates that the variables are significantly correlated for the fact that there is no variable with a value of 0.9 which indicates that there is no problem of multicollinearity (Pallant, 2007; Hair et al. 2010). 
Table 5. Pearson's Correlation between the Constructs

\begin{tabular}{|c|c|c|c|c|c|c|c|c|c|}
\hline & 1 & 2 & 3 & 4 & 5 & 6 & 8 & 9 & 10 \\
\hline IP & 1 & & & & & & & & \\
\hline AP & $.786^{* *}$ & 1 & & & & & & & \\
\hline TP & $.688^{* *}$ & $.274^{* *}$ & 1 & & & & & & \\
\hline CP & $.395^{* *}$ & .070 & .017 & 1 & & & & & \\
\hline$O C$ & $.331^{* *}$ & .093 & .065 & $.716^{* *}$ & 1 & & & & \\
\hline IG & $.534^{* *}$ & $.303^{* *}$ & $.271^{*}$ & * $.466^{* *}$ & $.542^{* *}$ & 1 & & & \\
\hline QT & $.174^{*}$ & .068 & $.122^{*}$ & $.216^{*}$ & $.754^{* *}$ & * $.439^{\circ}$ & $\begin{array}{l}* \\
*\end{array}$ & & \\
\hline WB & $.142^{* *}$ & .083 & -.018 & $.277^{* *}$ & $.468^{* *}$ & $.186^{*}$ & $.132^{* *}$ & $* 1$ & \\
\hline LS & -.004 & -.085 & .025 & .090 & .032 & .091 & .014 . & .025 & 1 \\
\hline TR & $.406^{* *}$ & $.437^{\circ}$ & -.015 & $.288^{* *}$ & $.341^{* *}$ & $.342^{* *}$ & $.185^{*}$ & $.163^{* *}$ & -.054 \\
\hline
\end{tabular}

\section{Conclusion}

This paper present individual performance, leadership succession, organizational climate and moderating effect of trust data screening which involved different processes in order to achieve the aim and objectives of the research. A good response rate of $75 \%$ was achieved which, covers all employees of commercial banks in the six states of the region. Response rate, non-respond biased data cleaning, detection of missing data, treatment of univariate and multivariate outliers and descriptive statistics and correlation has also been discussed in the paper.

\section{References}

Abdullahi, S. A. (2002). Distress in the Nigerian banking industry: A critical assessment of the nature, causes and extent. J. Bus. Administration, 2, 135-154.

Abraham, R. (1999) Emotional intelligence in organizations: a conceptualization. Genetic, Social and General Psychology Monographs $125,209-227$.

Adams, J. S. (1965). Inequity in social exchange. Advances in experimental social psychology, 2(267-299).

Apker, J., Propp, K. M., Zabava Ford, W. S., \& Hofmeister, N. (2006). Collaboration, credibility, compassion, and coordination: professional nurse communication skill sets in health care team interactions. Journal of Professional Nursing, 22(3),180- 189.

Argote, L. (1999). Organizational learning: Creating, retainingand transferring knowledge. Norwell, MA:Kluwer.

Argote, L., \& Ingram, P. (2000). Knowledge transfer: A basis for competitive advantage in firms. Organizational Behavior and Human Decision Processes, 82(1), 150-169

Babalola, Y. A. (2012). The determinants of bank's profitability in Nigeria. Journal of Money Ivestment and Banking (24).

Ballinger, G. A., \& Marcel, J. J. (2010). The use of an interim CEO during succession episodes and firm performance. Strategic Management Journal, 31(3), 262-283.

Ballinger, G. A., Schoorman, F. D., \& Lehman, D. W. (2009). Will you trust your new boss? The role of affective reactions to leadership succession. The Leadership Quarterly, 20(2), 219-232.

Blau, P. (1964). Exchange and power in social life. New York: John Wiley.

Bunderson, J. S., \& Sutcliffe, K. M. (2002). Comparing alternative conceptualizations of functional diversity in management teams: Process and performance effects. Academy of management journal, 45(5), 875-893.

Cannella Jr, A. A., \& Rowe, W. G. (1995). Leader capabilities, succession, and competitive context: A study of professional baseball teams. The Leadership Quarterly, 6(1), 69-88.

Chatterjee, S., Lubatkin, M. H., Lyon, E. M., \& Schulze, W. S. (1999). Toward a strategic theory of risk premium: Moving beyond CAPM. Academy of Management Review, 24(3), 556-567.

Child, J. (1972). Organizational structure, environment and performance: the role of strategic choice. Sociology, 6(1),1-22.

Ciarrochi, J., Chan A.Y.C. \& Caputi, P. (2000) A critical evaluation of the emotional intelligence concept. Personality and Individual Differences, 28, 1477-1490

Crosby, P.B. (1979). Quality is Free, McGraw-Hill, New York, NY.

Cropanzano, R., \& Mitchell, M, S. (2005). Social Exchange Theory: An Interdisciplinary Review. Journal of Management, 31 (6), $874-$ 900.

Cropanzano, R., Byrne, Z. S., Bobocel, D. R., \& Rupp, D. E. (2001). Moral virtues, fairness heuristics, social entities, and other denizens of organizational justice. Journal of Vocational Behavior, 58(2),164-209.

Creswell, J. W. (2003). Research design: Qualitative, quantitative and mixed methods approach (2th ed.), California, Saga Publication Inc.

Dawson, J. F, Roma, V. Davis, A. \& West, M. A. (2008). Organizational climate and climate strengthen UK hospitals. European Journal of Work and Organizational Psychology 17 (1), 89 - 111. 
Deming, W.E. (1986). Out of the Crisis, MIT Press, Cambridge, MA.

Deming, W.E. (1993). The New Economics, MIT Press, Cambridge, MA

Eisenhardt, K. M., \& Martin, J. A. (2000). Dynamic capabilities: what are they?.Strategic management journal, 21(10-11), 1105-1121.

Elmore, P. B., \& Beggs, D. L. (1975). Salience of Concepts and Commitment to Extreme Judgments in the Response Patterns of Teachers. Education, 95(4), 325-334.

Emerson, R. M. (1976). Social exchange theory, Annual Review of Sociology, 2: 335-362

Feigenbaum, A.V. (1991). Total Quality Control, McGraw-Hill, New York, NY.

Gardner, H.Gino, F \& Staats, B. (2012). Dynamically Integrating Knowledge in Teams: Transforming Resources into Performance. Academy of Management Journal 55, (4), 998-1022.

Garg, A. K, \& Weele, E. V. (2012). Succession Planning and Its Impact on the Performance of Small Micro Medium

Enterprises within the Manufacturing Sector in Johannesburg. International Journal of Business and Management 7, (9), 96-107.

Giambatista, R. C. (2004). Jumping through hoops: a longitudinal study of leader life cycles in the NBA. The Leadership Quarterly, 15(5), 607-624.

Gliem, J.A., Gliem, R. (2003). Calculating, interpreting and reporting cronbach's alpha Reliability coefficient for likert type scales. Midwest research practice conference In adult, continuing and community education.

Gramling, A.A., \& Myers, P.m. (1997). The perceived benefits of certified internal auditors Designation. America Accounting Association Accounting Horizons, 11(1), 39-53.

Gronin, M. A., \& Weingart, L. R. 2007. Representational gaps, information processing, and conflict in functionally diverse teams. Academy of Management Review, 32: 761-773.

Gruenfeld, D. H., Mannix, E. A., Williams, K. Y., \& Neale, M. A. (1996). Group composition and decision making: How member familiarity and information Distribution affect process and performance. Organizational Behavior and Human Decision Processes, 67 (1), 115.

Gruenfeld, D. H., Martorana, P. V., \& Fan, E. T. (2000). What do groups learn from their worldliest members?

Direct and indirect influence in dynamic teams. Organizational Behavior and Human Decision Processes, 82(1), 45-59.

Griffin, M.A., Neal, A. \& Parker, S.K. (2007). A new model of work role performance: Positive

Behavior in uncertain and interdependent contexts, Academy of Management Journal, 50 (2), 327-47.

Graffin, S. D., Carpenter, M. A., \& Boivie, S. (2011). What's all that (strategic) noise? anticipatory impression management in CEO succession. Strategic Management Journal, 32(7),748-770.

Guest, R . H. (1962). Managerial succession in complex organizations. American Journal of sociology, 68, 47-54.

Guimaraes, T. (1996). QM's impact on employee attitudes. The TQM Magazine, 8 (1), 20-5.

Hair, J. F., Andersen, R. E., \& Tatham, R. L.(2010). Multivariate data analysis (7thed.). Upper Saddle River, NJ: Pearson Prentice Hall.

Hoegl, M., \& Gemuenden, H. G. (2001). Teamwork quality and the success of innovative projects: A theoretical concept and empirical evidence. Organization science, 12(4), 435-449.

Iyiola, A. R. (2011, September). Gender and Racial Differentials in the Nigerian Banking International Journal of Business and Management 6(9)

Johnson, J. W. (2003). Toward a better understanding of the relationship between personality and individual job performance. Personality and work: Reconsidering the role of personality in organizations, 83-120.

Juran, J.M. (1993). Made in USA: a renaissance in quality. Harvard Business Review, 71(4), 42-50.

Juran, J.M. (1995). A History of Managing for Quality, ASQC Quality Press, Milwaukee, WI.

Juran, J.M. (1988). Juran's Quality Control Handbook, McGraw-Hill, New York, NY

Kane, A. A., Argote, L., \& Levine, J. M. (2005). Knowledge transfer between groups via personnel rotation: Effects of social identity and knowledge quality. Organizational Behavior and Human Decision Processes, 96(1), 56-71.

Karimi, L., Leggat, S. G., Donohue, L., Farrell, G., \& Couper, G. E. (2014). Emotional rescue: the role of emotional intelligence and emotional labour on well-being and job-stress among community nurses. Journal of advanced nursing, 70(1), 176-186.

Kolapo, T. F., Ayeni, R. K., \& Oke, M. O. (2012). Credit risk and commercial banks' performance in Nigeria: A panel model approach. Australian Journal of Business and Management Research, 2(2), 31-38.

Koopmans, L., Bernaards, C.M., Hildebrandt, V.H., Schaufeli, W.B., De Vet, H.C.W. \& Van der Beek, A.J. (2013),

Development of an individual work performance questionnaire, International Journal of Productivity and Performance Management, 62, (1), 6-28.

Krejcie, R. V., \& Morgan, D. W. (1970), Determining sample size for research activities. Educational and Psychological Measurement, 30, 601-610.

Krosnick, J. A., \& Fabrigar, L. R. (1997). Designing rating scales for effective measurement in surveys. Survey measurement and process quality, 141-164.

Kuei, C. H. (1999). Internal service quality-an empirical assessment.International Journal of Quality \& Reliability Management, 16(8), 783-791.

Leedy, P.D. \& Ormrod, J.E (2005). Practical research: Planning and design (8th Ed.), Saddle River, New Jersey: Prentice Hall.

Liu, Y., Valenti, M. A., \& Yu, H. Y. (2011). Presuccession Performance, CEO Succession, Top Management Team, and Change in a Firm's Internationalization:The Moderating Effect of CEO/Chairperson Dissimilarity. Canadian Journal of Administrative Sciences/Revue Canadienne des Sciences de l'Administration, 29(1), 67-78.

Malinowski, B. (1922). Argonauts of the western Pacific. New York: Dutton. 
Mauss, M. (1925). The gift: Forms and functions of exchange in archaic societies. New York: The Norton Library.

Ndofor, H. A., Priem, R. L., Rathburn, J. A., \& Dhir, A. K. (2009). What does the new boss think?: How new leaders' cognitive communities and recent "top-job" success affect organizational change and performance. The Leadership Quarterly, 20(5), 799813.

Nilniyom, P, \& Chanthinok, K. (2011). Accounting system innovation and stakeholder acceptance of Thai listed firms: Mediating internal control effectiveness. Review of Business Research, 11,(4) 26-37.

Nworji, I. D., Adebayo, O., \& David, A. O. (2011). Corporate governance and bank failure in Nigeria: Issues, challenges and opportunities. Research Journal of Finance and Accounting, 2(2), 25-42.

Nzotta, S. (2004). Money, Banking and Finance: Theory and Practice. Owerri: Hudson-Jude Nigeria Publishers.

Oakland, J.S. (1995). Total Quality Management, 2nd ed., Butterworth-Heinemann, Oxford.

Oghojafor, B. A., \& Adebisi, S. A. (2012). Evaluating Mergers and Acquisition as Strategic Interventions the Nigerian Banking Sector: The Good, Bad and the Ugly. International Business Research, 5(5), 147.

Patterson, M. G., West, M. A., Shackleton, V.J., Dawson, J.F., Lawthom, R., Maitlis, S., Robinson, D.L., \& Wallace, A.M. (2005). Validating the organizational climate measure: Links to managerial

Practices, productivity and innovation. Journal of Organizational Behavior, 26, 379-408.

Pallant, J. (2001). SPSS survival manual: A step by step guide to data analysis using SPSS for windows (3rd ed.). England:McGraw Hill open University Press.

Petrides, K.V. \& Furnham, A. (2000). On the dimensional structure of emotional intelligence. Personality and Individual differences, 29, 313-320.

Pulakos, E.D., Arad, S., Donovan, M.A. and Plamondon, K.E. (2000). Adaptability in the Workplace: Development of taxonomy of adaptive performance. Journal of Applied Psychology, 85(4), 612-24.

Randle, W. M. (1995). Delivering the future: Redefining the role of banks in new competitive environment. Bank Management, 7(1), 4558.

Rowe, W. G., Cannella Jr, A. A., Rankin, D., Gorman, D. (2005). Leader succession and organizational performance: Integrating the common-sense, ritual scapegoating, and vicious-circle succession theories. The Leadership Quarterly, 16(2), 197-219.

Sanusi, S. L. (2010a). Global financial meltdown and the reforms in the Nigerian Banking sector. Being the full text of a Public Lecture delivered at the Convocation Square, Abubakar Tafawa Balewa University, Bauchi. www.bis.org/review/r110124c.

Sacklofske, D.H., Austin E.J. \& Minski P.S. (2003) Factor structure and validity of a trait emotional intelligence measure. Personality and Individual Differences 34, 707-721.

Schutte, N.S. \& Malouff J.M. (1999) Measuring Emotional Intelligence and Related Constructs. E. Mellen Press, Lewiston, NY.

Settoon, R. P., Bennett, N., \& Liden, R. C. (1996). Social exchange in organizations: Perceived organizational support, leader-member exchange, and employee reciprocity. Journal of Applied Psychology, 8(13), 219-227.

Shossi, M. K, Witti, L.A \& Vera D. (2012). When does adaptive performance lead to higher task Performance? Journal of organizational behavior 33(7), 910-924.

Sophia, A. E. A. J. M. (2011). mergers and Acquisitions in the Nigerian banking Industry An Explorative Investigation Medwell Journals, 6(3), 213- 220.

Stadler, K. (2011). Talent reviews: the key to effective succession management Journal of human resources management 12 (5) $264-$ 271

Teece, D., Pisano, G., \& Shuen, A. (1997). Dynamic capabilities and strategic management. Strategic Management Journal, 18, 509533.

Terziovski, M., \& Samson, D. (1999). The link between total quality management practice and organisational performance. International Journal of Quality \& Reliability Management, 16(3), 226-237.

Theofanis, K., Drogalas, G, \& Giovanis, N. (2011). Evaluation of effectiveness of internal audit in Greek Hotel Business. International Journal of Economic Sciences and Applied Research, 4 (1), 19-34.

Van Vianen, A. E., De Pater, I. E., Bechtoldt, M. N., \& Evers, A. (2011). The strength and quality of climate perceptions. Journal of Managerial Psychology,26(1), 77-92.

Wayne, S. J., Shore, L. M., \& Liden, R. C. (1997). Perceived organizational support and leader-member exchange: A social exchange perspective. Academy of Management Journal, 40(1), 82-111.

Wiersema, M. F. (1995). Executive succession as an antecedent to corporate restructuring. Human Resource Management, 34(1), 185202.

Yang, T., Chen, M. C., \& Su, C. T. (2003). Quality management practice in semiconductor manufacturing industries- empirical studies in Taiwan. Integrated Manufacturing Systems, 14(2), 153-159.

Yen, H. R., Li, E. Y., \& Niehoff, B. P. (2008). Do organizational citizenship behaviors lead to information system success?: Testing the mediation effects of integration climate and project management. Information \& management, 45(6), 394-402.

Zajac, E., Kraatz, M., \& Bresser, R. (2000). Modeling the dynamics of strategic fit: A normative Approach to Strategic change. Strategic Management Journal, 21, 429- 453

Zollo, M., \& Winter, S. G. (2002). Deliberate learning and the evolution of dynamic capabilities. Organization science, 13(3), $339-351$.

Zuriekat, M., Salameh, R, \& Alrawashdeh, S. (2011). Participation in performance measurement Systems and level of satisfaction. International Journal of Business and Social Sciences, 2 (8),159-169. 